\title{
p53 re-expression inhibits proliferation and restores differentiation of human thyroid anaplastic carcinoma cells
}

\author{
Fabiola Moretti ${ }^{1,2}$, Antonella Farsetti ${ }^{1,2}$, Silvia Soddu ${ }^{1,3}$, Silvia Misiti ${ }^{1,3}$, Marco Crescenzi ${ }^{1,}$ \\ Sebastiano Filetti ${ }^{4}$, Mario Andreoli ${ }^{3}$, Ada Sacchi ${ }^{1}$ and Alfredo Pontecorvi ${ }^{1,5}$ \\ ${ }^{1}$ Molecular Oncogenesis Laboratory, 'Regina Elena' Cancer Institute; ${ }^{2}$ Institute of Experimental Medicine, National Research
Council (CNR); ${ }^{3} I I$ Chair of Endocrinology, University of Rome 'La Sapienza'; ${ }^{4}$ Chair of Endocrinology, University of Catanzaro;
${ }^{5}$ Institute of Medical Pathology, Catholic University, Rome, Italy
}

\begin{abstract}
Alterations of the tumor suppressor gene p53 are uncommon in differentiated thyroid neoplasia but are detected at high frequency in anaplastic thyroid carcinoma suggesting that impaired $\mathbf{p 3}$ function may contribute to the undifferentiated and highly aggressive phenotype of these tumors. Effects of wild type p53 (wtp53) re-expression were investigated in a human anaplastic thyroid carcinoma cell line (ARO) expressing a mutated p53. ARO cells were stably transfected with the temperature-sensitive p53 $\mathrm{Val}^{135}$ gene (ts-p53) which exhibits wild type-like activity at $32^{\circ} \mathrm{C}$. Exogenous wtp53 function in ARO-tsp53 clones was assessed by evaluating its transcriptional activity on a CAT reporter vector containing p53 binding sites. At $32^{\circ} \mathrm{C}$, a significant reduction in the proliferation rate $(\cong \mathbf{5 0 \%})$ was observed, with accumulation of cells in the $G_{0} / G_{1}$ phase of the cell cycle. This effect was accompanied by induction of the expression of the growth inhibitor p21/ Waf1 gene. At $32^{\circ} \mathrm{C}$, ARO-tsp53 clones also showed a marked impairment of their tumorigenic potential. Furthermore, transfected clones re-acquired the ability to respond to thyrotropin (TSH) stimulation showing an increased expression of thyroid-specific genes (thyroglobulin, thyroperoxidase and TSH receptor). In conclusion, re-expression of wt-p53 activity in ARO cells, inhibits cell proliferation and restores responsiveness to physiological stimuli.
\end{abstract}

Keywords: p53; tumor suppressor gene; differentiation; thyroid carcinoma

\section{Introduction}

Thyroid tumorigenesis is characterized by progressive impairment of cell differentiation, resulting in loss of the highly specialized functions of the thyrocyte and acquisition of a more malignant behaviour. Thyroid neoplasia, in fact, exhibit a wide variety of biological and clinical phenotypes which range from benign lesions such as micro/macro-follicular nodules and follicular adenomas, to malignant tumors such as differentiated follicular and papillary carcinomas and highly aggressive anaplastic carcinomas (Ingbar, 1985; Fagin, 1994). At the molecular level, these clinical and biological phenotypes are associated with accumula-

Correspondence: A Pontecorvi

Received 12 June 1996; revised 15 October 1996; accepted 15 October 1996 tion of specific genetic alterations, which lead to activation of oncogenes and/or inactivation of tumor suppressor genes, thought to play a key role in the development of thyroid neoplasia (Fagin, 1994). The proposed sequence of molecular events characterizing thyroid tumorigenesis, considers the alteration of the tumor suppressor gene p53 as a late event, since it has been found almost exclusively associated with poorly differentiated and anaplastic carcinomas (Wright et al., 1991; Ito et al., 1992; Nakamura et al., 1992; Fagin et al., 1993; Donghi et al., 1993). These tumor histotypes exhibit strong malignant behaviour, characterized by high invasiveness, complete loss of thyroid-specific biochemical markers, such as thyroglobulin (Tg), thyroperoxidase (TPO) and thyrotropin receptor (TSH-R), and impairment of thyroid differentiated functions such as iodine uptake, hormone secretion and response to thyrotropin (TSH) stimulation (Ingbar, 1985).

The frequent coexistence of p53 mutations with the most advanced and undifferentiated stages of tumors arising from various tissues (Prokocimer and Rotter, 1994; Grenblatt et al., 1994) and the inability of mutant p53 alone to induce malignant transformation of cell cultures (Hinds et al., 1989; Eliyahu et al., 1989; Battista et al., 1995) suggest that, at least for certain tumor histotypes, p53 alterations mostly contribute to the transition towards more malignant states rather than to the initiation of transformation. This hypothesis is also supported by p53-null mice, which develop normally but, in comparison to syngenic control animals, exhibit an altered tumor spectrum, characterized by the more frequent emergence, at an earlier age, of poorly differentiated carciomas (Donehower et al., 1992).

It has also been suggested that p53 plays a role in the process of cell differentiation and that p53 alterations may therefore interfere with cell commitment toward differentiation (Shaulsky et al., 1991b; Aloni-Grinstein et al., 1993; Battista et al., 1995; Fagin et al., 1996; Soddu et al., 1996). However, direct involvement of p53 along the pathway that leads to biochemical expression of cell-specific differentiation markers, is not completely defined, having been demonstrated only in selected cell types, such as those pertaining to the erythroleukemic lineage (Shaulsky et al., 1991a; Feinstein et al., 1992; Aloni-Grinstein et al., 1993; Johnson et al., 1993).

In the present study, we have investigated whether wild type p53 (wt-p53) is able to suppress the aggressive and undifferentiated phenotype of thyroid anaplastic carcinoma. A temperature-sensitive p53 
(ts-p53) has been stably transfected into a human undifferentiated thyroid carcinoma cell line (ARO) expressing a mutated p53. The tumor suppressor activity of wt-p53 has been evaluated at the permissive temperature $\left(32^{\circ} \mathrm{C}\right)$ in terms of cell proliferation, in vitro tumorigenic potential and thyroid-specific differentiation. The results show that recovery of wt-p53 activity reduces proliferation and tumorigenicity of ARO cells and restores their responsiveness to physiological differentiation stimuli.
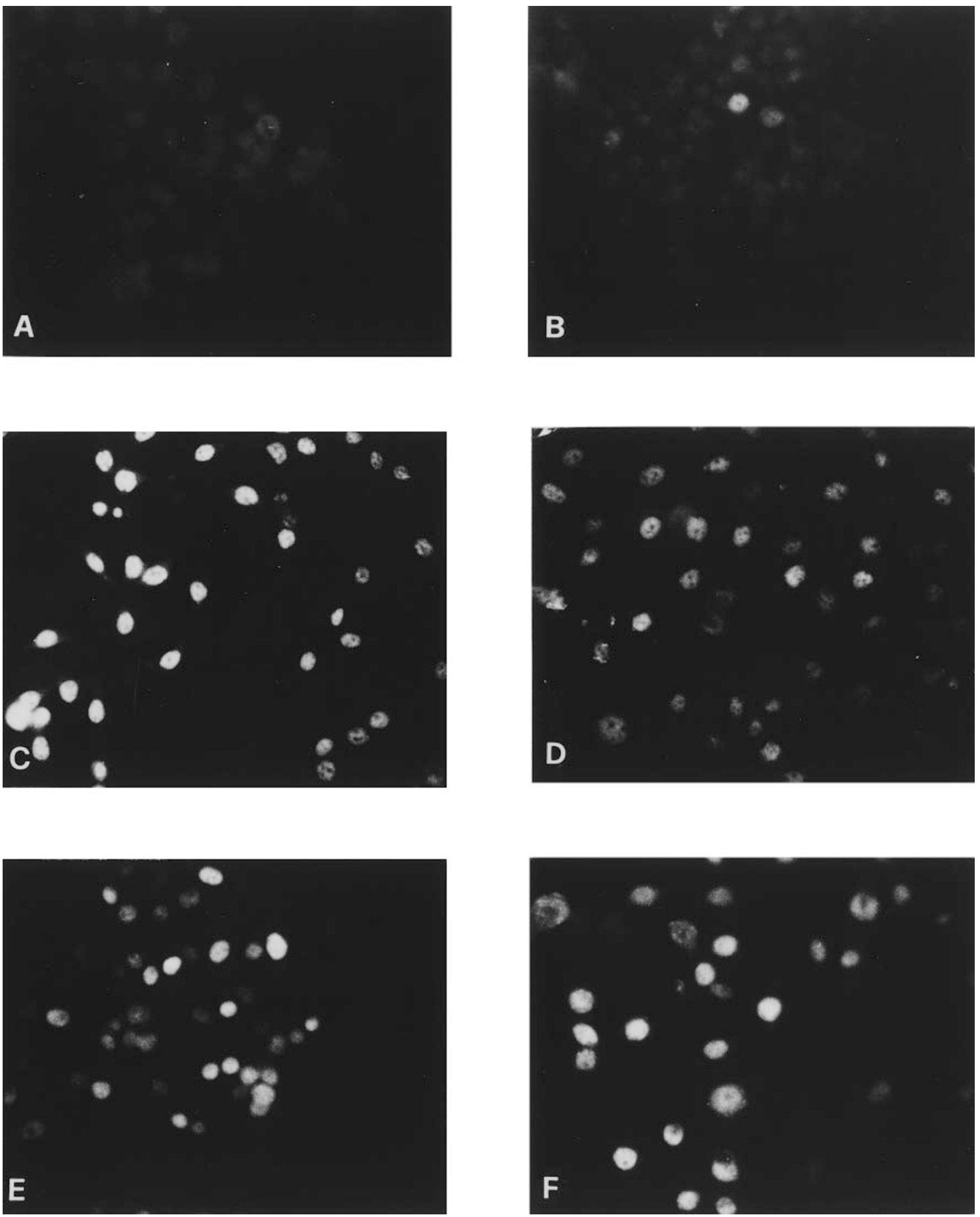

Figure 1 p53 expression in ARO clones by indirect immunofluorescence. ARO parental cells. (A), ARO-Neo (B) and ARO-tsp53 transfected clones, ARO-1F (C), ARO-4F (D), ARO-5 (E) and ARO-8 (F), were cultured in $35 \mathrm{~mm}$ Petri dishes, fixed and permeabilized. P53 expression was detected by immunofluorescence with PAb241 antibody as described under 'Materials and methods'. The level of p53 was assigned by semi-quantitative evaluation of the intensity of the immunofluorescence signal on 3 separate experiments, as follows: $\mathrm{ARO}-4 \mathrm{~F}<\mathrm{ARO}-8 \cong \mathrm{ARO}-5 \mathrm{~F}<\mathrm{ARO}-1 \mathrm{~F}$. Original magnification, $200 \times$ 
several clones were obtained. Parental cells and transfected clones were grown for 3 days at the permissive temperature $\left(32^{\circ} \mathrm{C}\right)$ and then assayed for the presence and localization of p53 protein by indirect immunofluorescence using monoclonal antibody $\mathrm{PAb} 421$. At $37^{\circ} \mathrm{C}$ the p53 fluorescence signal was mostly localized in the cytoplasm (data not shown). At $32^{\circ} \mathrm{C}$, ARO-tsp53 clones showed a marked fluorescence, predominantly localized at nuclear level, while ARO parental cells and ARONeo showed only a faint fluorescence. The nuclear localization at $32^{\circ} \mathrm{C}$ of ts-p53 in ARO transfected clones suggests the acquisition of wild type conformation (Ginsberg et al., 1991). On the basis of the immunofluorescence staining, four ARO-tsp53 positive clones, with varying degrees of fluorescence intensity (ARO-4F $<$ ARO-8 $\cong \mathrm{ARO}-5<\mathrm{ARO}-1 \mathrm{~F}$ ), and the control ARO-Neo, were selected (Figure 1). Each clone showed about $80 \%$ positive cells with heterogeneity in the nuclear staining, typical of p53 fluorescence (Ginsberg et al., 1991; Lu et al., 1992). The expression of p53 protein was further assessed by Western blot analysis (data not shown). Using the anti-p53 PAb240 antibody, which recognizes mutant mammalian p53 protein, two different bands, corresponding to the human endogenous and murine exogenous proteins, were observed, thus confirming the presence of the transfected ts-p53 in the selected clones. On the contrary, ARO parental and ARO-Neo cells generated a unique band corresponding to the endogenous $\mathrm{p} 53$.

\section{Transcriptional activity of exogenous wt-p53}

Several p53 mutant proteins, including the $\mathrm{His}^{273}$ present in ARO cells, act in a dominant-negative manner by forming mutant/wild type heterotetramers, thus interfering with the activity of wild type p53 (Milner and Medcalf, 1991; Kern et al., 1992; Donehower and Bradley, 1993). We therefore tested whether exogenous ts-p53, exhibiting wild type-like activity, might overcome the dominant negative action of the endogenous mutant protein.

The function of exogenous p53 was evaluated by measuring its transcriptional activity on a CAT reporter vector encompassing p53 binding sites ( $\left.\mathrm{PG}_{13}-\mathrm{CAT}\right)$. ARO-tsp53 (ARO-4F and ARO-1F) and ARO-Neo (control) cells were transiently transfected with $\mathrm{PG}_{13^{-}}$ CAT construct or a CAT construct containing a mutated sequence, unable to interact with wt-p53 ( $\left.\mathrm{MG}_{15}-\mathrm{CAT}\right)$. Figure 2 shows a significant induction of CAT activity in ARO-tsp53 clones transfected with the $\mathrm{PG}_{13} \mathrm{CAT}$ construct and maintained at $32^{\circ} \mathrm{C}$, but not in ARO$\mathrm{Neo}$ control cells. Interestingly, the induction of CAT activity directly correlated with the intensity of the p53 immunofluorescence staining exhibited by ARO-tsp53 clones (ARO-4F $<$ ARO-1F). The specificity of wt-p53 transcriptional activity was evidenced by the lack of CAT induction when the $\mathrm{MG}_{15}$-CAT construct was used (Figure 2). As expected, when ARO-tsp53 and ARONeo cells were incubated at $37^{\circ} \mathrm{C}$, CAT activity was absent, independently of the transfected constructs (data not shown). These findings demonstrate that, at the permissive temperature, ts-p53 expression generated adequate wild type-like activity in a cell context where a mutated dominant negative p53 is co-expressed.

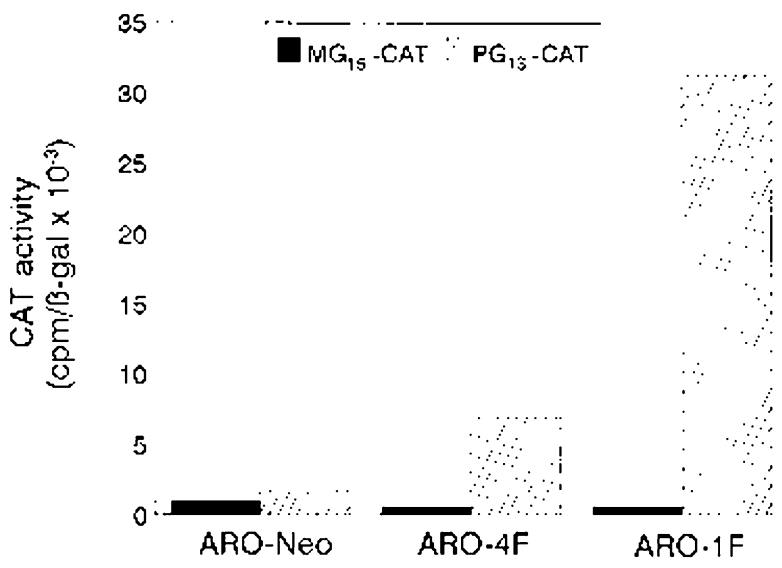

Figure 2 p53 transcriptional activity in ARO cell clones. Control ARO-Neo and ARO-tsp53 transfected clones, ARO-4F and ARO-1F were transfected with the reporter constructs $\mathrm{MG}_{15} \mathrm{CAT}$ and $\mathrm{PG}_{13} \mathrm{CAT}$ (filled and striped bars, respectively) by the calcium phosphate precipitation technique, as described under 'Materials and methods'. After removal of calcium phosphate precipitates, cells were cultured at $32^{\circ} \mathrm{C}$ in RPMI medium $+10 \%$ FCS. The CAT and $\beta$-galactosidase activities were determined on cellular extracts after $72 \mathrm{~h}$. Ratios of CAT $/ \beta$ galactosidase activities are expressed as counts/min/unit of $\beta$ galactosidase and are shown as the average of duplicate dishes from a representative experiment out of a total of three different experiments
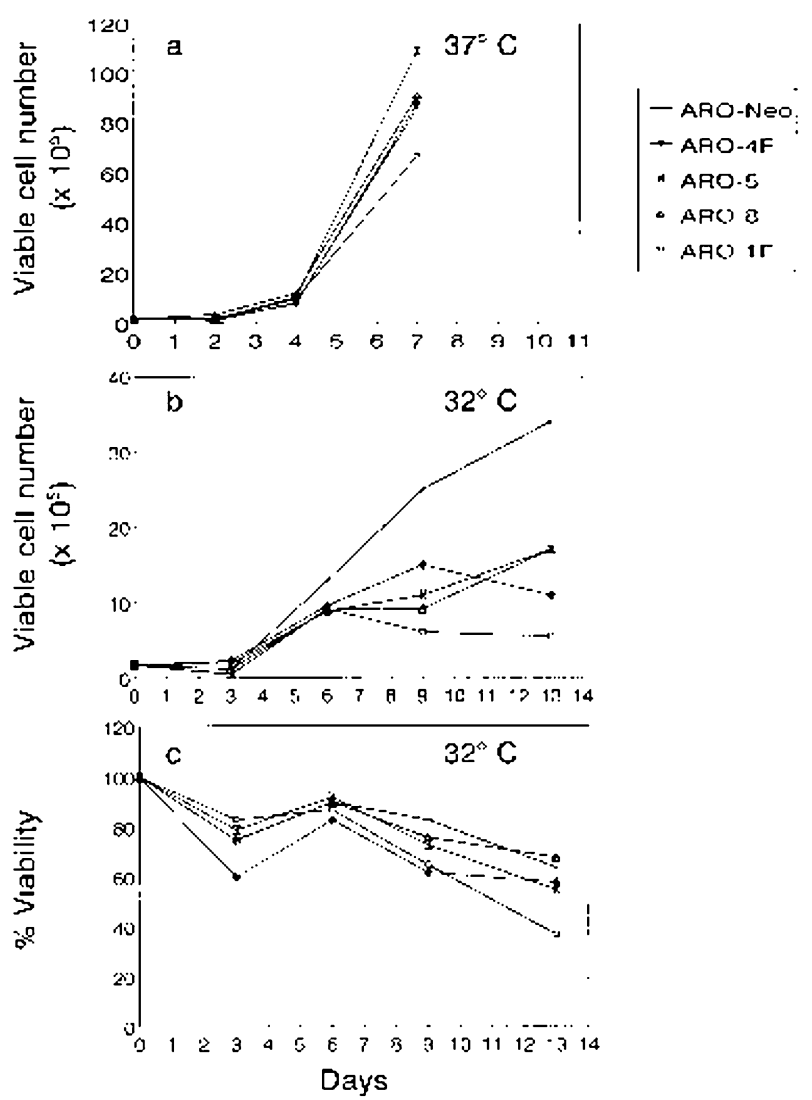

Figure 3 Analysis of growth rate of ARO cell clones. ARO clones were plated at a density of 6400 cells $/ \mathrm{cm}^{2}$ in $60 \mathrm{~mm}$ dishes and cultured for the indicated number of days before cell counting. Viable cells were determined by trypan blue exclusion after incubation at $37^{\circ} \mathrm{C}$ (a) or at $32^{\circ} \mathrm{C}$ (b); viability, estimated as percentage of viable cells, was evaluated at $32^{\circ} \mathrm{C}(\mathbf{c})$. The numbers represent the average of duplicate dishes from a typical experiment out of a total of 4 independent experiments. Symbols indicating the different clones are shown in the upper panel 

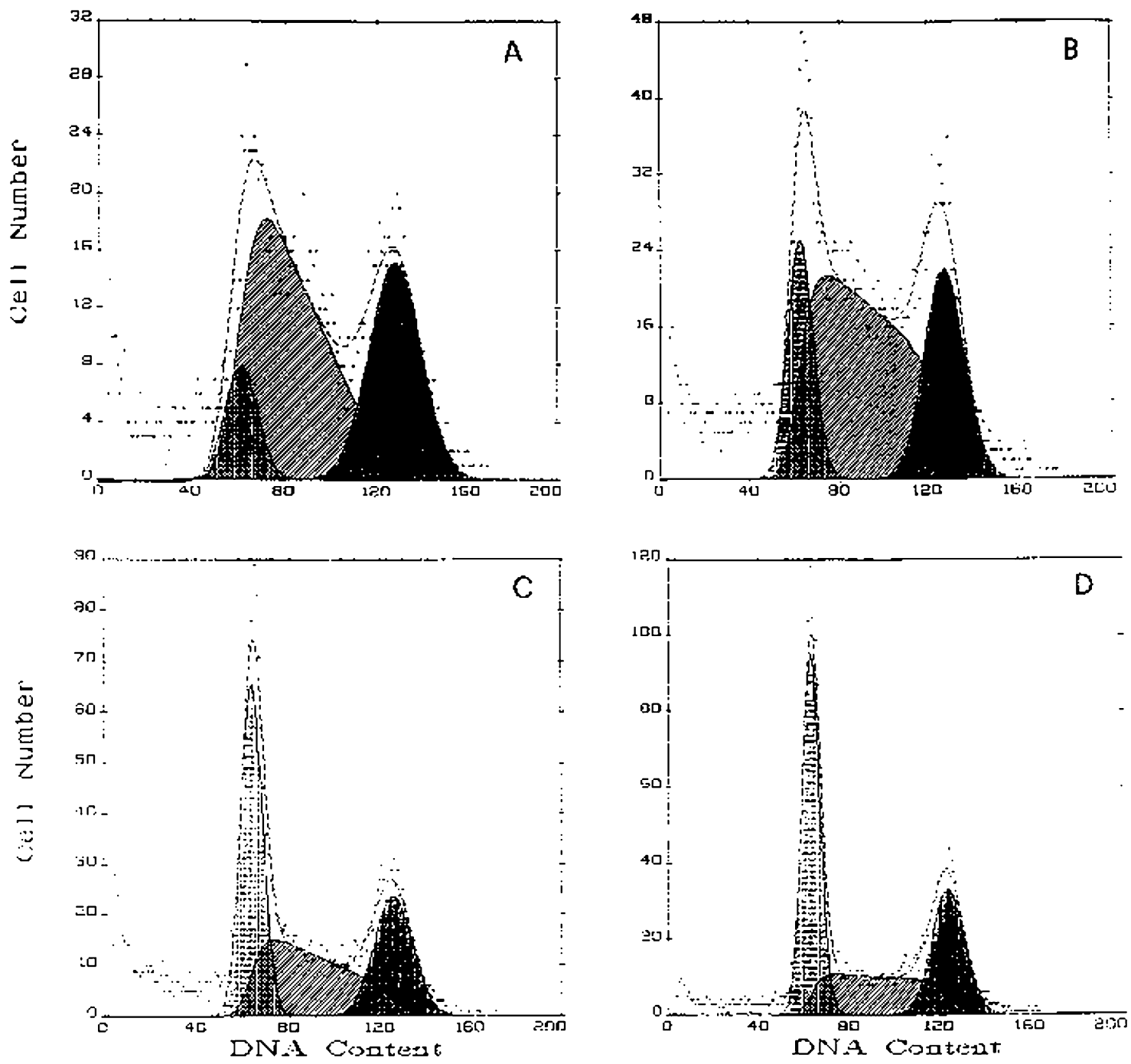

Figure 4 Cell cycle analysis of ARO cell clones. The histograms represent the cell cycle analysis performed on ARO parental cells (a), ARO-Neo (b) and ARO-tsp53 transfected clones, ARO-4F (c) and ARO-8 (d) maintained for 9 days at $32^{\circ} \mathrm{C}$. The DNA content was measured by detection of propidium iodide fluorescence, as described in 'Materials and methods'. (Dotted curves: $\mathrm{G}_{1}$ phase; striped curves: $\mathrm{S}$ phase; filled curves: $\mathrm{G}_{2} / \mathrm{M}$ phase)

\section{Wt-p53 inhibits ARO cell proliferation}

To study the tumor suppressor activity of exogenous p53, cell proliferation of ARO-tsp53 clones was evaluated. The proliferation rate of ARO-tsp53 clones was determined by counting the number of viable and dead cells. At $37^{\circ} \mathrm{C}$, all clones shared the same proliferation pattern (Figure 3a) indicating that, at this temperature, ts-p53 expression does not affect ARO cell growth. On the contrary, at $32^{\circ} \mathrm{C}$, the proliferation of the various ARO-tsp53 clones was significantly inhibited (Figure 3b).

Inhibition of cell proliferation by wt-p 53 may be the consequence of either an increase of cell death and/or accumulation in the $\mathrm{G}_{0} / \mathrm{G}_{1}$ phase of the cell cycle. However, when the viability rate was considered, no significant difference was observed between control ARO-Neo and ARO-tsp53 clones (Figure 3c), indicating that the reduction in the proliferation rate of AROtsp53 clones could not be attributed to an increase in p53-induced cell death.

The effect of ts-p53 on ARO cell proliferation was therefore evaluated by flow cytometric analysis of cellular DNA content. Cell cycle analysis, performed at day 9 on cells cultured at $32^{\circ} \mathrm{C}$, indicated that the percentage of cells in the $G_{0} / G_{1}$ phase was higher in ARO-tsp53 clones (ARO-4F and ARO-8) compared to controls (Figure 4). The corresponding DNA histograms did not show subdiploid peaks suggestive of apoptotic death, in good agreement with the cell viability profile reported in Figure 3c. To ascertain whether a progressive and time-dependent impairment of $\mathrm{G}_{1} / \mathrm{S}$ transition occurred, cell cycle analysis of AROtsp53 and control ARO-Neo and ARO parental cells, was performed at different day intervals. Analysis of cell proliferation index revealed a reduction of the progression of ARO-tsp53 cells into the growth fraction $\left(S+\mathrm{G}_{2} / \mathrm{M}\right)$ as compared to controls, indicating that, exogenous ts-p53 expression, rather than causing a progressive accumulation of cells in $\mathrm{G}_{1}$ generates a delay of $\mathrm{G}_{1} / \mathrm{S}$ transition, with an overall prolongation of the cell cycle (Table 1).

These data demonstrate that wt-p53 re-expression reduces ARO cell proliferation rate and causes a 
greater proportion of cells to reside in the $G_{0} / G_{1}$ phase of the cell cycle, without significant induction of apoptotic cell death.

\section{p21/Waf1 induction in ARO cells}

The $\mathrm{p} 21 /$ Waf1 inhibitor of cyclin-dependent kinases is believed to be the main downstream effector of p53 action in the $G_{1}$ phase of the cell cycle (Hunter, 1993; El-Deiry et al., 1994; Slebos et al., 1994). We therefore verified whether the inhibition of cell proliferation observed in ARO-tsp53 clones was associated with transcriptional regulation of the $\mathrm{p} 21 / \mathrm{Waf} 1$ gene by analysing its mRNA levels in ARO-tsp53 and ARONeo clones cultured at $37^{\circ} \mathrm{C}$ or $32^{\circ} \mathrm{C}$ for a total period of 7 days. As expected, at $37^{\circ} \mathrm{C}$, p21 mRNA levels were not induced, showing a barely detectable signal (Figure $5)$. On the contrary, a strong increase $(14-88$ relative fold induction over values at $37^{\circ} \mathrm{C}$ ) of $\mathrm{p} 21 / \mathrm{Waf} 1 \mathrm{mRNA}$ levels was observed in ARO-tsp53 cells cultured at $32^{\circ} \mathrm{C}$ (Figure 5 and Table 2, w/o TSH). Almost undetectable p21/Waf1 mRNA expression was also observed in ARO-Neo cells, independently of culture conditions.

These results indicate that, in ARO-tsp53 cells, the effect of wt-p53 re-expression on cell proliferation is, at least in part, mediated by transcriptional induction of the $\mathrm{p} 21 /$ Waf1 gene.

\section{$W t$-p53 reduces in vitro tumorigenic potential of $A R O$} cells

A relatively good parameter to evaluate the effectiveness of a tumor suppressor agent is the ability to inhibit

Table 1 Proliferation index of ARO cell clones

\begin{tabular}{lllll}
\hline & \multicolumn{4}{c}{$G 1 /(S+G 2 / M)$} \\
Cells & $1 d$ & $6 d$ & $9 d$ & $15 d$ \\
\hline ARO & $1.6^{*}$ & 0.45 & 0.19 & 0.36 \\
ARO-Neo & 1.2 & 0.44 & 0.23 & 0.42 \\
ARO-4F & 1.2 & 0.8 & 0.6 & 0.55 \\
ARO-8 & 1.8 & 1.12 & 0.8 & 0.9 \\
\hline
\end{tabular}

*Values are the average of $\mathrm{G} 1 /(\mathrm{S}+\mathrm{G} 2 / \mathrm{M})$ ratios from two independent experiments colony formation in a semisolid medium. A soft-agar assay was therefore performed to evaluate whether exogenous wild type p53 action might reduce the in vitro tumorigenic potential of ARO-tsp53 clones. After 2 weeks incubation at $32^{\circ} \mathrm{C}$ (Figure 6a), the ability of ARO-tsp53 clones to form colonies ( $>50$ cells/colony) was strongly reduced (ARO-1F, ARO-5 and ARO-8 cells: 0 colonies/plate; ARO-4F cells: $\leqslant 3$ colonies/plate) in comparison to controls (parental ARO and ARONeo cells: $>80$ colonies/plate). On the contrary, at $37^{\circ} \mathrm{C}$ (Figure 6b), all clones exhibited a strong anchorageindependent growth $(>200$ colonies/plate for each clone). The lower number of colonies obtained after parental ARO and ARO-Neo cells incubation at $32^{\circ} \mathrm{C}$, as compared to $37^{\circ} \mathrm{C}$, was dependent upon the lower incubation temperature used, total colony number approaching that observed at $37^{\circ} \mathrm{C}$ after extension of cell incubation at $32^{\circ} \mathrm{C}$ for an additional week.

These data clearly indicate that wt-p53 re-expression is able to suppress the in vitro tumorigenic potential of ARO cells.

\section{Wt-p53 restores thyroid-specific differentiation in ARO cells}

Among the different thyroid tumor histotypes, anaplastic carcinoma shows the unique association between loss of thyroid differentiation properties and alteration of p53 function. Recent reports have suggested that p53, other than acting as an inhibitor of cell proliferation, could also play a role in the process of cell differentiation (Shaulsky et al., 1991b;

Table 2 Quantitation of p21 mRNA levels

\begin{tabular}{|c|c|c|}
\hline \multirow[b]{2}{*}{ Cells } & \multicolumn{2}{|c|}{ Relative fold induction* } \\
\hline & $w / o T S H$ & with TSH \\
\hline ARO-Neo & - & - \\
\hline ARO-1F & 88 & 207 \\
\hline ARO-4F & 41 & 65 \\
\hline ARO-5 & 14 & 45 \\
\hline ARO-8 & 57 & 58 \\
\hline
\end{tabular}

* Relative fold induction of p21 mRNA levels, at $32^{\circ} \mathrm{C}$ vs $37^{\circ} \mathrm{C}$, after normalization for GAPDH mRNA levels
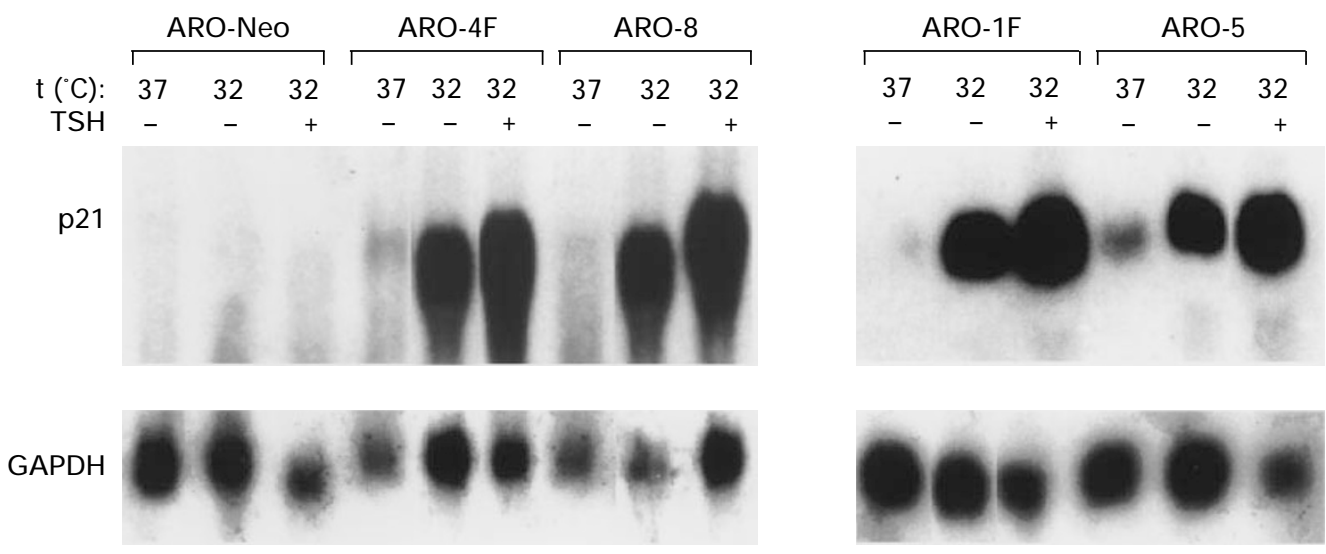

Figure 5 Expression and TSH responsiveness of p21/WAF1 gene in ARO cell clones. Northern blot analysis was performed on total RNA extracted from control ARO-Neo and the indicated ARO-tsp53 transfected clones, cultured at $37^{\circ} \mathrm{C}(37)$ or at $32^{\circ} \mathrm{C}(32)$ for 4 days and maintained, for further 3 days, in the presence $(+)$ or absence $(-)$ of $10 \mathrm{mU} / \mathrm{ml}$ TSH. RNA was size-fractionated on a $1.2 \%$ agarose gel, vacuum-blotted on a Duralose membrane, hybridized with ${ }^{32}$ P-labeled p21/WAF1 cDNA and assessed by autoradiography (upper panel). Membranes were rehybridized with the house-keeping ${ }^{32} \mathrm{P}$-labeled GAPDH cDNA (lower panel) to determine RNA loading 
Aloni-Grinstein et al., 1993; Battista et al., 1995; Fagin et al., 1996; Soddu et al., 1996). For these reasons we investigated whether wt-p53 re-expression could also modulate the impaired thyroid differentiation pathway of ARO cells. Expression of the thyroid-specific genes $\mathrm{Tg}$, TPO and TSH-R, was evaluated by measuring cytoplasm mRNA levels in the various ARO clones. In agreement with Namba et al. (1992), who reported that ARO cells express very low levels of TSH-R mRNA, detectable only by RT - PCR analysis, we were not able to detect Tg, TPO and TSH-R mRNA signals by Northern analysis. The three thyroid-specific mRNAs and the house-keeping aldolase mRNA, co-amplified as an external standard, were therefore analysed by semiquantitative RT-PCR, performed at least 9 times starting from three different RNA preparations.
Negative (no template) and positive (human thyroid RNA) controls were run to check for DNA and PCR product contaminations as well as to properly set up semi-quantitative RT-PCR conditions (see Materials and methods) (Figure 7a). mRNAs for TSH-R, Tg and TPO were all present, although at very low levels, in all ARO clones (Figure 7b). In particular, in unstimulated conditions, expression of these genes in ARO-tsp53 clones was not moditifed after incubation either at $37^{\circ} \mathrm{C}$ or $32^{\circ} \mathrm{C}$, as indicated by the ratios between mRNA levels at the two temperatures (Figure $7 \mathrm{~b}$, subscribed numbers). Hence, we can conclude that wtp53 re-expression per se does not appear to affect ARO cell differentiation.

Thyrocytes exhibit specialized functions and express thyroid-specific biochemical markers, such as Tg, TPO

a
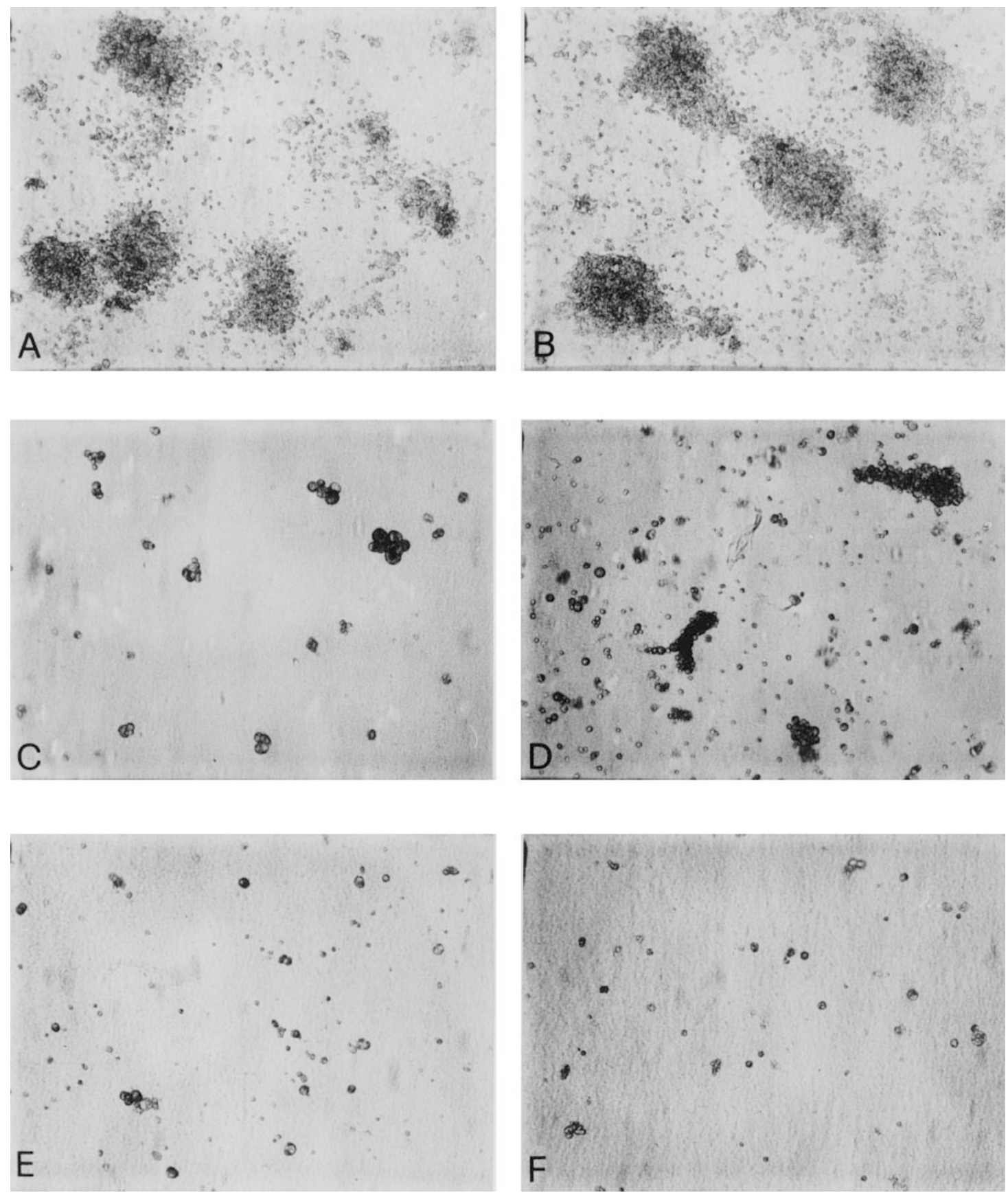
b
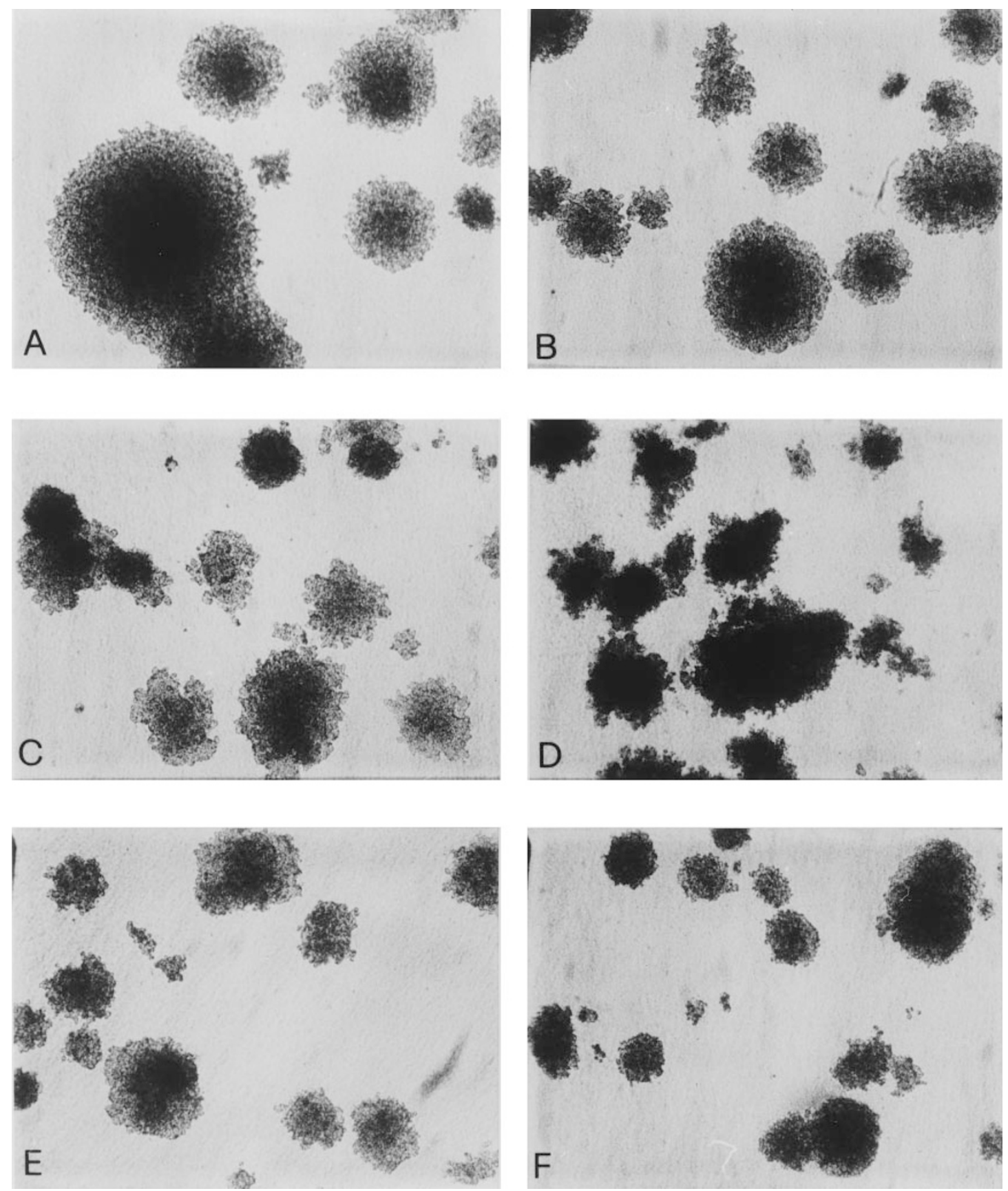

Figure 6 Anchorage-independent growth of ARO cell clones. ARO parental cells (A), ARO-Neo (B), and the different ARO-tsp53 transfected clones, ARO-1F (C), ARO-4F (D), ARO-5 (E) and ARO-8 (F), were seeded in soft-agar and investigated for their ability to form colonies ( $>50$ cells/colony), following 2 weeks incubation at $32^{\circ} \mathrm{C}$ (a) or at $37^{\circ} \mathrm{C}$ (b). (a) ARO-1F, ARO-5 and ARO8 cells $=0$ colonies/plate; ARO- $4 \mathrm{~F}$ cells $=\leqslant 3$ colonies/plate; parental ARO and ARO-Neo cells $=>80$ colonies/plate. (b) total colony number $=>200 /$ plate for each clone

and TSH-R, which are modulated by TSH. ARO cells, however, are TSH-independent, both in terms of proliferation and expression of thyroid-specific genes (Namba et al., 1992). Since it has been reported that wt-p53 is able to restore responsiveness to cytokine signals in leukemic cells (Yonish-Rouach et al., 1991; Johnson et al., 1993), we investigated whether AROtsp53 clones re-acquired responsiveness to the thyrocyte physiological stimulus, TSH. To this purpose, expression of thyroid-specific genes was investigated in ARO-tsp53 clones, cultured at $32^{\circ} \mathrm{C}$ for 4 days and then for further 3 days in the presence or absence of a standard TSH concentration $(10 \mathrm{mU} / \mathrm{ml})$. TSH- R, Tg and TPO mRNA levels were all markedly increased following TSH stimulation (Figure 8). On the contrary, ARO-Neo and ARO parental cells did not show any variation in the expression of thyroid-specific genes, regardless of TSH presence. The possibility that the increased expression of thyroid-specific mRNAs could be due to a generalized increase of transcription induced by $\mathrm{TSH}$ was ruled out by the observation that mRNA levels for the house-keeping aldolase gene 

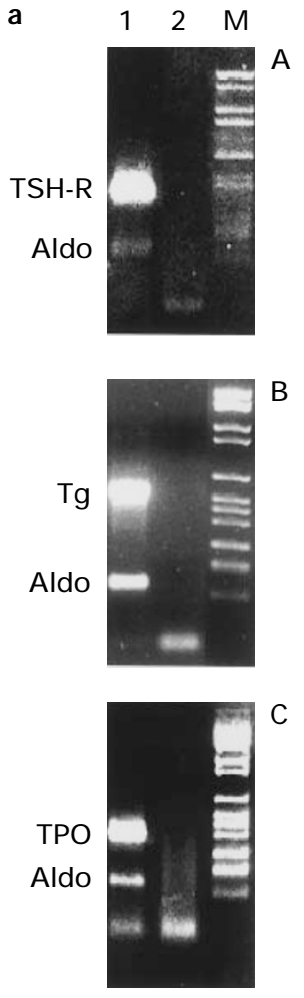

b
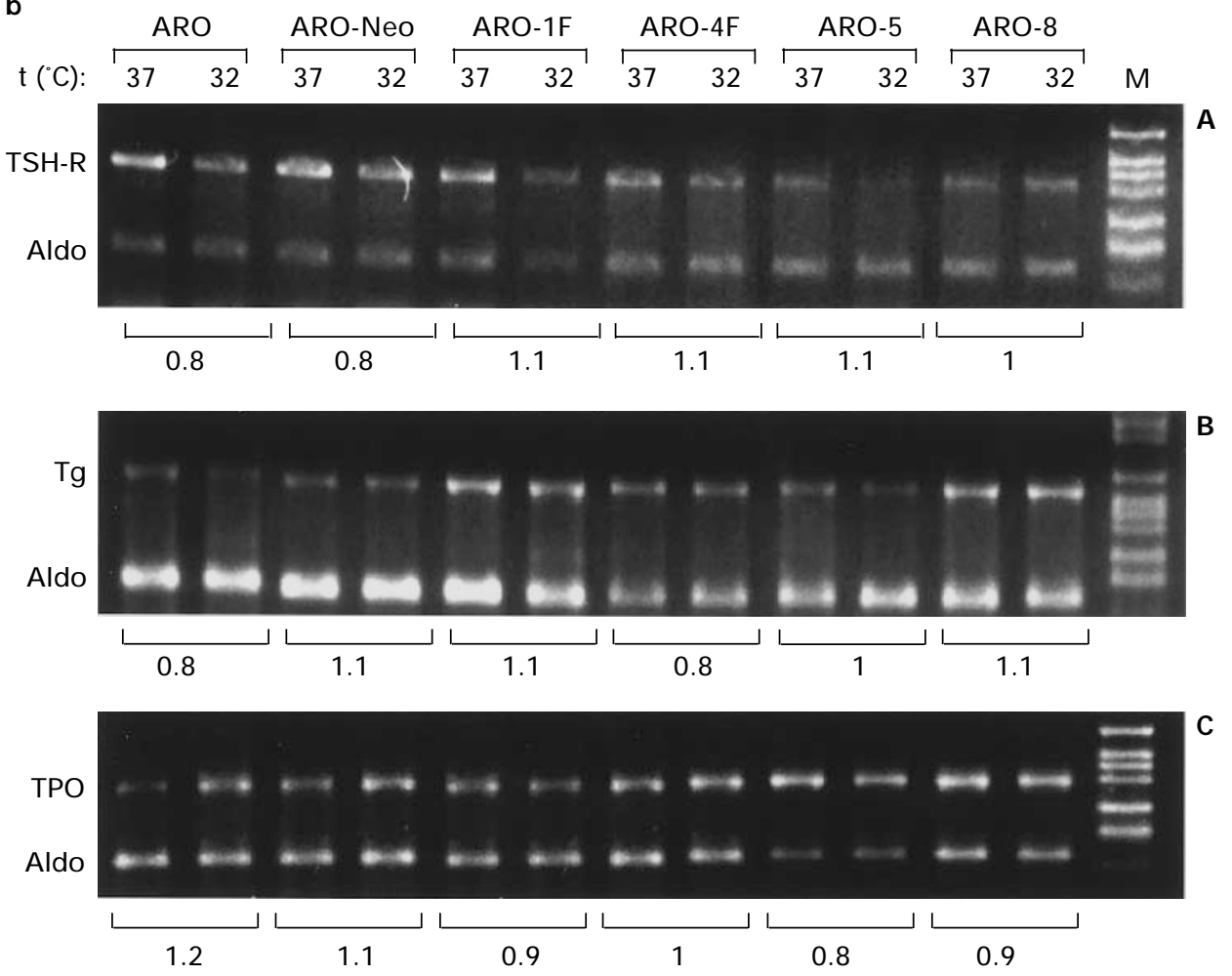

Figure 7 Expression of thyroid specific genes in ARO cell clones. Total RNA was extracted from ARO cell clones grown at $37^{\circ} \mathrm{C}$ or at $32^{\circ} \mathrm{C}$ and $\mathrm{RT}-\mathrm{PCR}$ analysis performed by using intron-spanning primers specific for the thyroid-specific genes: TSH receptor (TSH-R; row A), thyroglobulin (Tg; row B) and thyroperoxidase (TPO; row C). The relative intensity of the bands was quantitated by densitometry and normalized to the co-amplified aldolase signal (Aldo). Normalized values were used to calculate ratios (subscribed numbers), at $37^{\circ} \mathrm{C}$ vs $32^{\circ} \mathrm{C}$, for each thyroid-specific marker. (a) lane 1 , human thyroid RNA; lane 2 , no cDNA template. (b) expression of thyroid mRNAs in different ARO clones at $37^{\circ} \mathrm{C} \mathrm{(37)}$ or at $32^{\circ} \mathrm{C}(32)$. M, molecular size marker (Marker VI, Boehringer Mannheim)

were constant in all culture conditions tested (Figure 8, Aldo). These data suggest that wt-p53 re-expression is able to restore ARO cell responsiveness to TSH stimulation.

It has been recently reported that induction of differentiation is accompanied by an increased expression of p21/Waf1 gene (Steinman et al., 1994; Jiang et al., 1994; Parker et al., 1995; Macleod et al., 1995). Expression of p21/Waf1 was therefore investigated in ARO-tsp53 clones, cultured at $32^{\circ} \mathrm{C}$ in the presence or absence of TSH. The results showed that, in three ARO-tsp53 clones (ARO-1F, ARO-4F and ARO-5), p21/Waf1 mRNA levels, already increased following wt-p53 re-expression, raised after $\mathrm{TSH}$ addition to culture medium (Figure 5 and Table 2, with TSH). It is therefore possible to speculate that TSH stimulation, while inducing thyroid-specific gene expression, is also able to modulate $\mathrm{p} 21 / \mathrm{Waf} 1$, in agreement with the hypothesis underlying a role for this gene in the process of cell differentiation.

\section{Discussion}

Functional alterations of the tumor suppressor p53 gene in thyroid neoplasia, have been found almost exclusively in poorly differentiated and anaplastic thyroid carcinomas (Wright et al., 1991; Ito et al., 1992; Nakamura et al., 1992; Fagin et al., 1993; Donghi et al., 1993). In this regard it is noteworthy the observations by Donghi et al. (1993) who found that, inside a thyroid tumor composed by two areas with varying degrees of differentiation, p53 gene mutation was restricted to the less differentiated area of the neoplasia. These observations have raised the hypothesis that derangement of $\mathrm{p} 53$ function could be correlated to the loss of the differentiated properties of the thyrocyte and to the acquisition of the highly invasive and aggressive behaviour of undifferentiated thyroid carcinomas.

In this study we have investigated the possibility that re-expression of wild type-p53 in human thyroid anaplastic carcinoma cells may interfere with their neoplastic behaviour and/or modulate the re-acquisition of thyrocyte differentiation properties. For this purpose, we have stably transfected a temperaturesensitive mutant p53 into the human thyroid anaplastic carcinoma cell line ARO, which expresses a mutant (His ${ }^{273}$ ) p53 allele while lacking the other allele.

The results demonstrate that recovery of wt-p53 activity in ARO cells, provides for (1) a strong reduction in the proliferation rate which coincides with an accumulation in the $G_{1}$ phase of the cell cycle, (2) a complete loss of the in vitro tumorigenic potential, (3) the reappearance of typical thyrocyte differentiated properties, such as the induction of the thyroid specific genes Tg, TPO and TSH-R upon TSH stimulation.

The present findings, demonstrating the ability of wt-p53 in reducing ARO cell proliferation rate, are in keeping with those reported in the literature concerning the growth inhibitory activity of p53 in transformed cell lines (Michalovitz et al., 1990; 

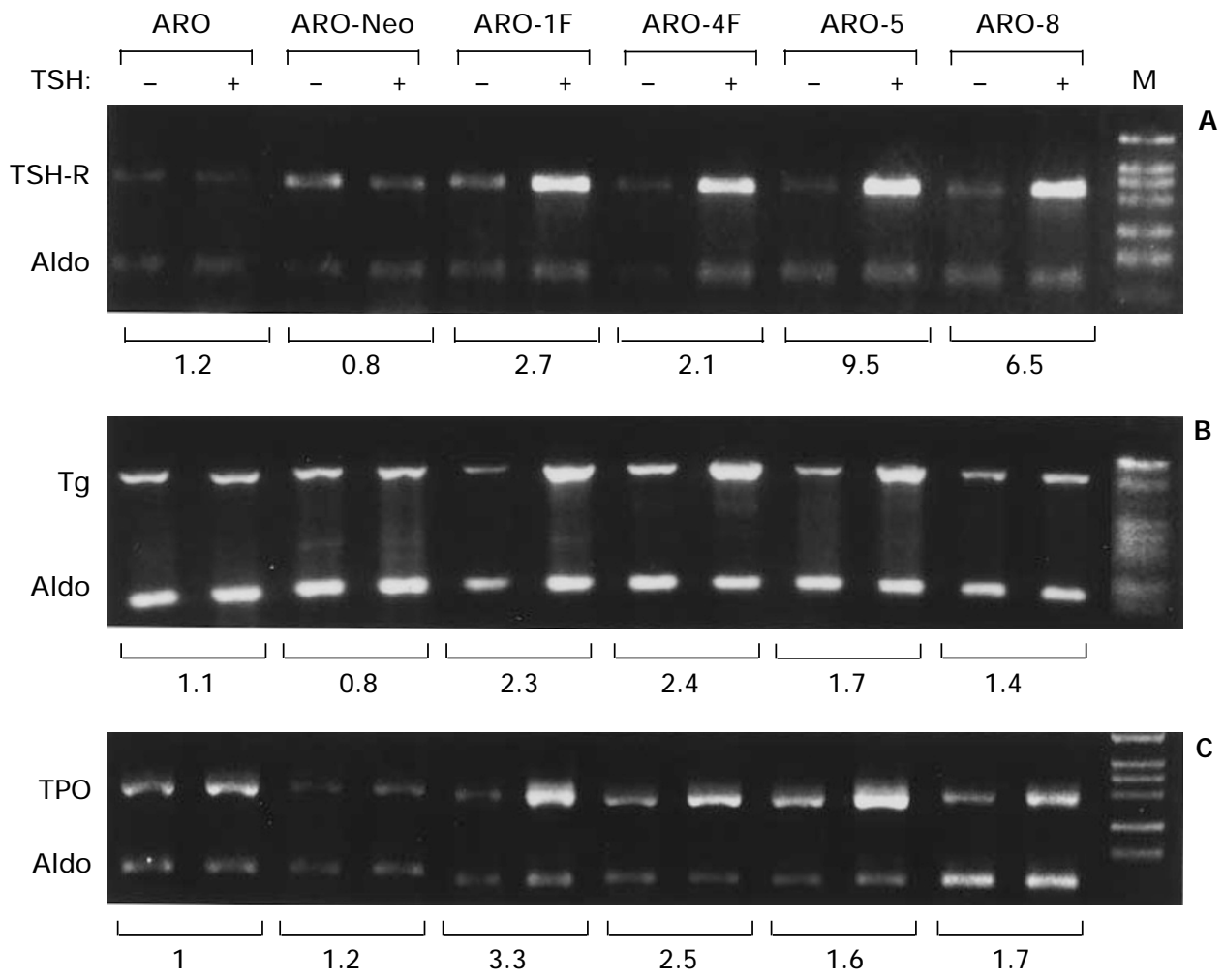

Figure 8 TSH responsiveness of ARO cell clones. Total RNA was extracted from ARO cell clones grown for 4 days at $32^{\circ} \mathrm{C}$ and for a further 3 days in the presence $(+)$ or absence $(-)$ of $10 \mathrm{mU} / \mathrm{ml}$ TSH. RT $-\mathrm{PCR}$ analysis was performed by using intronspanning primers specific for the thyroid-specific genes: TSH receptor (TSH-R; row A), thyroglobulin (Tg; row B) and thyroperoxidase (TPO; row C). The relative intensity of the bands was quantitated by densitometric analysis and normalized to the co-amplified aldolase mRNA signal (Aldo). Normalized values were used to calculate ratios (subscribed numbers), in TSH stimulated $(+\mathrm{TSH})$ vs unstimulated $(-\mathrm{TSH})$ conditions, for each thyroid-specific marker. M, molecular size marker (Marker VI, Boehringer Mannheim)

Mercer et al., 1990; Baker et al., 1990; Shaulsky et al., 1991b; Feinstein et al., 1992; Johnson et al., 1993; Fagin et al., 1996). The coupling of wild type p53 function with inhibition of the progression from $G_{0} / G_{1}$ to the $\mathrm{S}$ phase of the cell cycle, is a well characterized finding and appears to be mediated by increased p21/ Waf1 expression. In agreement with these observations, our results show that inhibition of cell proliferation in ARO-tsp53 clones is accompanied by a delay of the $G_{1} / S$ transition and by induction of p21/Waf1 gene expression. The inhibition of AROtsp53 cell proliferation did not appear to be caused by increased cell death, as judged by estimation of cell viability curves and cell cycle analysis. However, it cannot be excluded that attainment of higher expression levels of exogenous p53 might modulate a final outcome generating cell death instead of growth inhibition. Indeed, in HL60 cells, differentiation and apoptosis depend upon the levels of wt-p53 expression reached after vaccinia virus infection (Ronen et al., 1996).

It has been reported that induction of differentiation in human hematopoietic cells and in pre-B and B cells is accompanied by p53 upregulation (Kastan et al., 1991; Aloni-Grinstein et al., 1993) and that overexpression of wt-p53 in transformed cell lines induces the expression of specific differentiation markers (Shaulsky et al., 1991b; Feinstein et al., 1992; Johnson et al., 1993; Brenner et al., 1993; Soddu et al., 1994; Fagin et al., 1996). In this regard, we analysed whether re-expression of wt-p53 in ARO cells was able to induce the expression of thyroid differentiation markers (Tg, TPO and TSH-R). The results showed that wt-p53 re-expression is not able per se to modulate the expression of these markers. However, following TSH treatment, ARO-tsp53 clones exhibited a differentiated phenotype with increased expression of $\mathrm{Tg}$, TPO, and TSH-R mRNAs. In keeping with these results are recent observations showing that wt-p53 overexpression in transformed cell lines is able to modulate their responsiveness to appropriate stimuli (Yonish-Rouach et al., 1991; Brenner et al., 1993; Johnson et al., 1993). Therefore, re-expression of wt-p53 in ARO cells leads to restoration of responsiveness to their physiological stimulus. This effect might be due to a recovery of the $\mathrm{TSH}$ receptor transduction pathway, since it has been shown that, in ARO cells, TSH receptor is able to bind its ligand with unaltered affinity but shows an impaired function, probably due to a defect in the receptorcoupling system (Pang et al., 1989; Namba et al., 1992; Kimura et al., 1992). Another explanation relies on the hypothesis that re-expression of wt-p53 could act by 'normalizing' the transformed phenotype of ARO cells, thus rendering them again responsive to exogenous and/or endogenous stimuli. The latter hypothesis is also supported by the finding that ARO-tsp53 cells completely loose their in vitro tumorigenic potential.

Interestingly, TSH-R mRNA was positively regulated following TSH treatment, a finding which may contrast with the 'down-regulation' usually elicited by hormones toward their specific receptors. Our observations, however, are in good agreement with the results 
obtained by Huber et al. (1992) and Maaenhaut et al. (1992) in human thyroid monolayer cells, which also demonstrated upregulation of TSH-R expression following TSH stimulation. Receptor recruitment is also a characteristic of other pituitary glycoproteic hormones such as FSH, a phenomenon which is used in current therapeutic protocols for the induction of ovulation in the infertile women.

Attempts to demonstrate the re-acquistion of more complex, thyrocyte function, such as iodine uptake or cAMP stimulation, were also performed in ARO-tsp53 clones but the results were negative. We do not know whether this lack of effect is due to an incomplete recovery of thyroid-specific differentiation or it is the consequence of the low cell incubation temperature $\left(32^{\circ} \mathrm{C}\right)$ which is necessary to elicit wt-p53 activity. The latter hypothesis is supported by the marked decrease of iodine uptake showed at $32^{\circ} \mathrm{C}$ also by control rat FRTL-5 cells, a cell line which possess a fair ability to trap iodine.

In agreement with the hypothesis that p53 plays a role in thyrocyte differentiation, two recent reports substantiate a direct involvement of p53 in the thyroid differentiation process. Battista et al. (1995) showed that transfection of a mutated p53 in a nontransformed rat thyroid cell line interfered with thyroid-specific functions, particularly by inhibiting the expression of Pax-8, a transcription factor involved in thyroid-specific gene expression. A mirror image of these results was obtained by Fagin et al. (1996) who showed a positive effect on the thyroidspecific enzyme TPO and on Pax-8 expression, following transfection of a wt-p53 in a human thyroid papillary carcinoma cell line characterized by the presence of a heterozygous p53 mutation. Although both studies confirm a possible role of p53 along the thryoid differentiation pathway, the latter is not entirely comparable to ours, mainly because of differences in the cellular and genetic context and because the effect of TSH stimulation was not investigated.

In our model, the partial re-acquisition of a thyroid differentiation phenotype is also accompanied by increase of $\mathrm{p} 21 \mathrm{Waf} 1 / \mathrm{mRNA}$ levels in the presence of $\mathrm{TSH}$. This result is in agreement with recent reports suggesting that $\mathrm{p} 21 / \mathrm{Waf} 1$ is an early marker of differentiation, which contributes to cell cycle arrest and cell differentiation by distinctive pathways (Steinman et al., 1994; Parker et al., 1995).

In conclusion, our results indicate that wt-p53 reexpression in human thyroid anaplastic carcinoma cells can interfere and partially revert their malignant and undifferentiated phenotype. In this respect, attempts at exploring the possibility of 'normalizing' neoplastic thyroid cell behaviour may be of interest in view of future applications in the clinical practice.

\section{Materials and methods}

\section{Cell cultures, plasmids and transfections}

The human thyroid anaplastic carcinoma cell line, ARO, was cultured in RPMI 1640 medium supplemented with $10 \%$ heat-inactivated fetal bovine serum (Gibco-BRL, Life Technologies). ARO cells are characterized by the deletion of one p53 allele and by the presence, on the other allele, of a $\mathrm{G}: \mathrm{C}$ to $\mathrm{A}: \mathrm{T}$ transition at codon 273 , resulting in the substitution of an arginine with a histidine residue (Fagin et al., 1993). This mutation is responsible for the alteration of p53 transcriptional activity, due to impairment of p53 binding to the specific DNA recognition sites on target genes (Cho et al., 1994).

Plasmid pN53cG $\left(\mathrm{Val}^{135}\right)$, coding for the temperature sensitive murine $\mathrm{p} 53 \mathrm{Val}^{135}$ mutant gene, and the selectable marker neo, under the control of the RSV-LTR promoter (tsp53), was used to stably transfect ARO cells. The p53 Val ${ }^{135}$ protein has a mutant conformation at $37^{\circ} \mathrm{C}$ while displays a wild type-like activity at $32^{\circ} \mathrm{C}$ (Gisberg et al., 1991). The plasmid pRSVneo (Neo), carrying only the selectable marker neo under the control of the RSV-LTR promoter, was used as control. Approximately, $2 \times 10^{6}$ exponentially growing ARO cells were stably transfected by electroporation $(0.25 \mathrm{~V}, 960 \mu \mathrm{F})$ with a Gene Pulser (Bio-Rad Laboratories Inc., Hercules, CA). Single cell clones were selected in medium containing $1 \mathrm{mg} / \mathrm{ml} \mathrm{G} 418$ (Gibco-BRL).

Plasmid $\mathrm{PG}_{13} \mathrm{CAT}$, carrying the CAT reporter gene driven by the polyoma virus early promoter and 13 repeats of a $\mathrm{p} 53$ binding sequence, or plasmid $\mathrm{MG}_{15} \mathrm{CAT}$, containing 15 repeats of a mutated p53-binding site (Kern et al., 1992), were transiently transfected in ARO cells clones by calcium phosphate precipitation technique. In $60 \mathrm{~mm}$ plates, $4 \times 10^{5}$ cells were transfected with aliquots of precipitates containing: (1) $10 \mu \mathrm{g}$ of $\mathrm{PG}_{13} \mathrm{CAT}$ or $\mathrm{MG}_{15} \mathrm{CAT}$ or SV40CAT; (2) $1 \mu \mathrm{g}$ of $\mathrm{CMV} \beta$-gal plasmid, an internal control of transfection efficiency. Cells were harvested $72 \mathrm{~h}$ after transfection and CAT activity was assayed on whole cell extracts as described (Desvergne et al., 1991).

\section{Proliferation rate and cell cycle analysis}

Cell proliferation rate was assessed by determining cell number in a Thomas's hemocytometer, using Trypan blue exclusion as cell viability test. Cell cycle profile was evaluated by fixing $2 \times 10^{5}$ cells in cold acetone: methanol $(1: 4)$ for $30 \mathrm{~min}$ at $4^{\circ} \mathrm{C}$ and staining DNA for $30 \mathrm{~min}$ at room temperature with $50 \mu \mathrm{g} / \mathrm{ml}$ propidium iodide in PBS containing $1 \mathrm{mg} / \mathrm{ml}$ RNAse A. Cellular DNA content was measured by an Epics XL analyser (Coulter Corp, Miami, FL) by acquiring at least $10^{4}$ events/sample. The percentage of cells in the different cell cycle compartments was estimated by applying a mathematical model to each histogram, based on the maximum likelihood approach (Lampariello et al., 1991).

\section{Anchorage-independent growth}

To determine the ability of the various ARO clones to form colonies in soft agar, $1 \times 10^{4}$ cells were seeded in $60 \mathrm{~mm}$ dishes onto $0.3 \%$ Noble Agar on top of a $0.6 \%$ bottom layer. Colonies larger than 50 cells were scored after 2 weeks incubation either at $32^{\circ} \mathrm{C}$ or $37^{\circ} \mathrm{C}$.

\section{Northern blot analysis}

Total RNA was extracted by the guanidinium isothiocyanate acidic phenol method (Chomczynski and Sacchi, 1987) from ARO clones, incubated, either at $32^{\circ} \mathrm{C}$ or $37^{\circ} \mathrm{C}$ for 4 days, and then, for additional 3 days, in the presence or absence of TSH $(10 \mathrm{mU} / \mathrm{ml}) .25 \mu \mathrm{g}$ of total RNA/lane were separated on a $1.2 \%$ agarose-formaldehyde gel, vacuumblotted on a Duralose membrane (Stratagene), covalently bound by brief u.v. exposure, hybridized to radiolabeled probes for $12 \mathrm{~h}$ and autoradiographed. Densitometric analysis of autoradiograms was performed on a GS-700 Imaging Densitometer (Bio Rad, CA, USA) and results expressed as relative fold of induction, at $32^{\circ} \mathrm{C}$ vs $37^{\circ} \mathrm{C}$, after normalization for control GADPH mRNA levels. 


\section{$R T-P C R$ analysis of thyroid-specific $m R N A s$}

RT-PCR was performed as described (Kawasaki, 1990) with minor modifications: $5 \mu \mathrm{g}$ of total RNA were reverse transcribed at $42^{\circ} \mathrm{C}$ for $45 \mathrm{~min}$ in the presence of random examers and Moloney murine leukemia virus reverse transcriptase (Gibco-BRL). $5 \mu \mathrm{l}$ of the cDNA reaction were then subjected to PCR in a final volume of $50 \mu \mathrm{l} \mathrm{PCR}$ buffer $(50 \mathrm{mmol} / \mathrm{l} \mathrm{KCl}, \quad 10 \mathrm{mmol} / \mathrm{l}$ Tris- $\mathrm{HCl}, \quad \mathrm{pH} 8.3$, $1.5 \mathrm{mmol} / 1 \mathrm{MgCl}_{2}, 0.01 \%$ gelatin) containing $200 \mu \mathrm{mol} / 1$ each dNTP, 0.5 units Taq polymerase (Perkin Elmer, Norfolk, CT, USA) and $0.4 \mu \mathrm{mol} / 1$ of specific intronspanning primers.

Tg mRNA analysis was carried out by PCR amplification of a fragment of $544 \mathrm{bp}$ using the following primers: forward primer (exon 1: 6-27), 5'-CCTGGTCCTGGAGATCTTCACC-3', reverse primer (exon 5: 550-529) 5'-AACACTGGGGTGGTGACTTATC-3'. PCR was performed for a total of 35 cycles, each consisting of $1 \mathrm{~min}$ at $94^{\circ} \mathrm{C}$, $1 \mathrm{~min}$ at $58^{\circ} \mathrm{C}$, and $1 \mathrm{~min}$ at $72^{\circ} \mathrm{C}$. For TSH-R mRNA analysis, a fragment of $410 \mathrm{bp}$ was obtained, using the following primers: forward primer (exon 7: 690-710) 5'TCAATGGGACAAAGCTGGAT-3', reverse primer (exon 10: $\quad 1100-1080) \quad 5^{\prime}$-TGCTGTCACCCAGATTCTCT-3 (Namba et al., 1992). PCR was performed for a total of 40 cycles, with a profile similar to that used for $\mathrm{Tg}$, except for the annealing temperature of $65^{\circ} \mathrm{C}$. For TPO mRNA analysis, a fragment of $386 \mathrm{bp}$ was obtained, using the following primers: forward primer (exon 12: 2185-2205) 5'AACACTGGCCTCACCAGGGT- $3^{\prime}$, reverse primer (exon 14: 2571-2551) 5'-TCCGCGCAGAGACACTGGAA-3'. PCR was performed for a total of 40 cycles with the same profile used for $\mathrm{Tg}$ analysis, except for the annealing temperature of $58^{\circ} \mathrm{C}$. The house-keeping aldolase mRNA was used as external standard and co-amplified, in the same reaction tube, with the other thyroid-specific markers, using the following primers: forward primer 5'-CAGCTCCTTCTTCTGCTGCGGGGTC-3', reverse primer 5'-CGCAGAAGGGGTCCTGGTGA-3' (Chelly et al., 1988). PCR conditions were the same as those used for the amplification of each single thyroid-specific cDNA fragment.

PCR products were electrophoresed onto a $2 \%$ agarose gel containing ethidium bromide $(0.5 \mu \mathrm{g} / \mathrm{ml})$ and visualized under u.v. light. The relative intensity of the bands was quantitated by densitometric analysis and normalized to the co-amplified aldolase cDNA fragment. Preliminary experiments were performed to determine the exponential phase of amplification for each marker using RNA extracted from human normal thyroid tissue as positive control. The optimal ratio between the different primer couples, used in amplifying aldolase and the various thyroid-specific markers, was: $1: 1$ for Tg, 1:4 for TSH-R, and $1: 2$ for TPO. Densitometric values were used to calculate ratios for each thyroid-specific marker under the different incubation conditions. At least 9 RT-PCR experiments were performed starting from three different RNA preparations, obtained after incubation of ARO cell clones, either at $37^{\circ} \mathrm{C}$ or $32^{\circ} \mathrm{C}$, in the presence or absence of TSH, as described above. No amplification of fragments longer than the expected bands was ever observed in the RT-PCR experiments, indicating lack of interference from potential DNA contaminants. Negative controls without cDNA were also run at the beginning and at the end of each single PCR experiment to check for contamination by products from previous PCR.

\section{Indirect immunofluorescence}

Approximately $4 \times 10^{4}$ ARO cells were plated on a $35 \mathrm{~mm}$ Petri dish and grown at $32^{\circ} \mathrm{C}$ for 3 days. Cells were fixed in acethone:methanol $(1: 1)$ for $5 \mathrm{~min}$ at room temperature, rehydrated and incubated for $1 \mathrm{~h}$ at $37^{\circ} \mathrm{C}$ with monoclonal antibody PAb421 (Oncogene Science, Uniondale, NY) which recognizes $\mathrm{p} 53$ protein of a broad range of mammalian species. After washing, cells were incubated for $1 \mathrm{~h}$ with FITC-conjugated goat anti-mouse IgG. Localization and intensity of fluorescence were observed with fluorescence microscopy.

\section{Western blot analysis}

Approximately $5 \times 10^{6}$ cells, cultured at $37^{\circ} \mathrm{C}$, were incubated for $30 \mathrm{~min}$ at $4^{\circ} \mathrm{C}$ in lysis buffer $(20 \mathrm{mM}$ Tris, pH 7.8; $50 \mathrm{mM} \mathrm{NaCl} ; 5 \mathrm{~mm}$ EDTA; $1 \%$ Triton X-100; $0.2 \%$ SDS; $0.5 \%$ Sodium deoxycholate; $1 \mathrm{~mm}$ PMSF). The lysate was centrifuged at $10000 \mathrm{~g}$ for $30 \mathrm{~min}$ and the protein content in the supernatant measured (Bio-Rad). Fifty $\mu \mathrm{g}$ of proteins per sample were loaded onto a $10 \%$ SDS-polyacrylamide gel, electrophoresed, and then electroblotted onto nitrocellulose membranes (Bio-Rad). Filters were blocked for non-specific reactivity by incubation for $1 \mathrm{~h}$ at room temperature in $2 \%$ non-fat dry milk dissolved in TBST $(20 \mathrm{~mm}$ Tris- $\mathrm{HCl}$ pH $7.8 ; 150 \mathrm{mM} \mathrm{NaCl} ; 0.02 \%$ Tween 20), and then probed with anti-p53 PAb240 antibody (Oncogene Science), diluted in TBST at a concentration of $0.5 \mathrm{mg} / \mathrm{ml}$ for $2 \mathrm{~h}$ at room temperature under gentle rocking. PAb240 antibody recognizes mutant p53 protein on a broad mammalian spectrum. P53 immunoreactivity was determined using ECL-chemiluminescence reaction (Amersham Corp, Arlington Heights, IL) following manufacturer's instructions.

\section{Acknowledgements}

The authors wish to thank Dr GJF Juillard (UCLA) for the generous gifts of the ARO thyroid anaplastic carcinoma cell line and Professor F Eusebi and Dr Aldo Giovannelli for technical support in intracellular calcium determination. They are also especially grateful to Marian Shields for manuscript editorial assistance and to the administrative staff of the Institute of Experimental Medicine (CNR).

This work was supported by research grants from Associazione Italiana per la Ricerca sul Cancro (AIRC), Consiglio Nazionale delle Richerche (CNR), Ministero dell'Università e della Ricerca Scientifica e Tecnologica (MURST) and Ministero della Sanità.

\section{References}

Aloni-Grinstein R, Zan-Bar I, Alboum I, Goldfinger N and Rotter V. (1993). Oncogene, 8, 3297-3305.

Baker SJ, Markowitz S, Fearon ER, Willson JKV and Vogelstein B. (1990). Science, 249, 912-915.

Battista S, Martelli ML, Fedele M, Chiappetta G, Trapasso F, De Vita G, Battaglia C, Santoro M, Viglietto F, Fagin JA and Fusco A. (1995). Oncogene, 11, 2029-2037.

Brenner L, Munoz-Antonia T, Vellucci VF, Zhou Z and Reiss M. (1993). Cell Growth and Diff., 4, $993-1004$.

Chelly J, Kaplan JC, Maire P, Gautron S and Kahn A. (1988). Nature, 333, 858-860.

Chomczynski P and Sacchi N. (1987). Anal. Biochem., 162, $156-159$.

Cho Y, Gorina S, Jeffrey PD and Pavletich NP. (1994). Science, 265, 346-355.

Desvernge B, Petty KJ and Nikodem VM. (1991). J. Biol. Chem., 266, 1008 - 1013. 
Donehower LA, Harvey M, Slagle BL, McArthur MJ, Montgomery Jr CA, Butel JS and Bradley A. (1992). Nature, 356, 215-221.

Donehower LA and Bradley A. (1993). Biochim. Biophys. Acta, 1155, 181-205.

Donghi R, Longoni A, Pilotti S, Michieli P, Della Porta G and Pierotti MA. (1993). J. Clin. Invest., 91, 1753-1760.

El-Deiry WS, Harper JW, O'Connor PM, Velculescu VE, Canman CE, Jackman J, Pietenpol JA, Burrell M, Hill DE, Wang Y, Wiman KG, Mercer EW, Kastan MB, Kohn KW, Elledge SJ, Kinzler KW and Vogelstein B. (1994). Cancer Res., 54, $1169-1174$.

Eliyahu D, Michalovitz D, Eliyahu S, Pinhasi-Kimhi O and Oren M. (1989). Proc. Natl. Acad. Sci. USA, 86, $8763-$ 8767.

Fagin JA, Matsuo K, Karmakar A, Chen DL, Tang S and Koeffler HP. (1993). J. Clin. Invest., 91, 179-184.

Fagin JA. (1994). Thyroid Today, 17, 1-7.

Fagin JA, Tang SH, Zeki K, Di Lauro R, Fusco A and Gonsky R. (1996). Cancer Res., 56, $765-771$.

Feinstein E, Gale RP, Reed J and Canaani E. (1992). Oncogene, 7, $1853-1857$.

Ginsberg D, Michael-Michalovitz D, Ginsberg D and Oren M. (1991). Mol. Cell. Biol., 11, 582-585.

Greenblatt MS, Bennett WP, Hollstein M and Harris CC. (1994). Cancer Res., 54, 4855-4878.

Hinds PW, Finlay CA and Levine AJ. (1989). J. Virol., 63 , $739-746$.

Huber GK, Weinstein SP, Graves PN and Davies TF. (1992). Endocrinology, 130, 2858-2864.

Hunter T. (1993). Cell, 75, $839-841$.

Ingbar SH. (1985). Williams Textbook of Endocrinology. Wilson JD and Foster DW. (eds). W.B. Saunders Company: Philadelphia, pp. $682-815$.

Ito $\mathrm{T}$, Seyama $\mathrm{T}$, Mizuno $\mathrm{T}$, Tsuyama $\mathrm{N}$, Hayashi $\mathrm{T}$, Hayashi $\mathrm{Y}$, Dohi $\mathrm{K}$, Nakamura $\mathrm{N}$ and Akiyama $\mathrm{M}$. (1992). Cancer Res., 52, $1369-1371$.

Johnson P, Chung S and Benchimol S. (1993). Mol. Cell. Biol., 13, 1456-1463.

Jiang H, Lin J, Su Z, Collart FR, Huberman E and Fisher PB. (1994). Oncogene, 9, 3397-3406.

Kastan MB, Radin AI, Kuerbitz SJ, Onyekwere O, Wolkow CA, Civin CI, Stone KD, Woo T, Ravindranath Y and Craig RW. (1991). Cancer Res., 51, 4279-4286.

Kawasaki ES. (1990). PCR Protocols: A guide to Methods and Applications. Innis MA, Gelfand DH, Sninsky JJ and White TJ. (eds). Academic Press, Inc: San Diego, pp. 21 27.

Kern SE, Pietenpol JA, Thiagalingam S, Seymour A, Kinzler KW and Vogelstein B. (1992). Science, 256, 827-830.

Kimura H, Yamashita S, Namba H, Usa T, Fujiyama K, Tsuruta M, Yokoyama N, Izumi $\mathrm{M}$ and Nagataki $\mathrm{S}$. (1992). Exper. Cell. Res., 203, 402-406.
Lampariello F, Sebastiani G, Cordelli E and Spanò $M$. (1991). Cytometry, 12, 343-349.

Lu X, Park SH, Thompson TC and Lane DP. (1992). Cell, 70, $153-161$.

Macleod KF, Sherry N, Hannon G, Beach D, Tokino T, Kinzler K, Vogelstein B and Jacks T. (1995). Genes Dev., 9, $935-944$.

Maenhaut C, Brabant G, Vassart G and Dumont JE. (1992). J. Biol. Chem., 267, 3000-3007.

Mercer WE, Shields MT, Amin M, Sauve GJ, Apella E, Romano JW and Ullrich SJ. (1990). Proc. Natl. Acad. Sci. USA, 87, 6166-6170.

Michalovitz D, Halevy O and Oren M. (1990). Cell, 62, $671-$ 680.

Milner J and Medcalf EA. (1991). Cell, 65, 765-774.

Nakamura T, Yana I, Kobayashi T, Shin E, Karakawa K, Fujita S, Miya A, Mori T, Nishisho I and Takai S. (1992). Jpn. J. Cancer Res., 83, 1293-1298.

Namba H, Yamashita S, Usa T, Kimura H, Yokoyama N, Izumi M and Nagataki S. (1992). Endocrinol., 132, 839845.

Parker SB, Eichele G, Zhang P, Rawls A, Sands AT, Bradley A, Olson EN, Harper JW and Elledge SJ. (1995). Science, 267, $1024-1027$.

Pang XP, Hershman JM, Chung M and Pekary EA. (1989). Endocrinology, 125, 1783-1788.

Prokocimer M and Rotter V. (1994). Blood, 84, 2391-2411.

Ronen D, Schwartz D, Teitz Y, Goldfinger N and Rotter V. (1996). Cell Growth and Differ., 7, 21-30.

Shaulsky G, Goldfinger N and Rotter V. (1991a). Cancer Res., 51, $5232-5237$.

Shaulsky G, Goldfinger N, Peled A and Rotter V. (1991b). Proc. Natl. Acad. Sci. USA, 88, 8982-8985.

Slebos RJC, Lee MH, Plunkett BS, Kessis TD, Williams BO, Jacks T, Hedrick L, Kastan MB and Cho KR. (1994). Proc. Natl. Acad. Sci. USA, 91, 5320-5324.

Soddu S, Blandino G, Citro G, Scardigli R, Piaggio G, Ferber A, Calabretta B and Sacchi A. (1994). Blood, 83, $2230-2237$.

Soddu S, Blandino G, Scardigli R, Coen S, Marchetti A, Rizzo MG, Bossi G, Cimino L, Crescenzi M and Sacchi A. (1996). J. Cell. Biol., 134, 193-204.

Steinman RA, Hoffman B, Iro A, Guillouf C, Liebermann DA and El-Houseini ME. (1994). Oncogene, 9, $3389-$ 3396.

Yonish-Rouach E, Resnitzky D, Lotem J, Sachs L, Kimchi A and Oren M. (1991). Nature, 352, 345-347.

Wright PA, Lemoine NR, Goretzki PE, Wyllie FS, Bond J, Crristine H, Roher HD, Williams ED and WynfordThomas D. (1991). Oncogene, 6, 1693-1697. 